\title{
ENTRE JÁTA Y WAWEAMU: VIH/SIDA EN LAS COMUNIDADES AWAJÚN DE LA AMAZONÍA PERUANA
}

\author{
Ximena Flores Rojas ${ }^{1}$ \\ ${ }^{1}$ Universidade Federal do Rio de Janeiro, Rio de Janeiro/RJ, Brasil
}

Mi primer ingreso al distrito de El Cenepa ${ }^{1}$, en el año 2014, dejó en mí profundas marcas. Junto a un equipo de antropólogos entré a este territorio del pueblo awajún con el objetivo de promover un protocolo de atención en salud en las comunidades afectadas por el VIH/SIDA. Ahí conocí a dos de las principales comunidades de este distrito y a Jorge, un joven awajún seropositivo de 19 años. Su situación de dolor, su resistencia y la desesperación de su familia, me dieron la sensación de vidas indígenas silenciadas por una epidemia creciente. Desde 2002, los Awajún del distrito de El Cenepa vienen luchando contra el VIH/SIDA. En ese año, según algunas madres, comenzaron los primeros rumores de una enfermedad desconocida traída por los apách (personas no indígenas) y en 2005², se registró la primera muerte por "SIDA" en el distrito. Desde entonces, esta condición es una de las mayores preocupaciones de las familias awajún que ven multiplicarse los casos de muerte precoz entre sus hijos: “iNosotros viejos no estamos muriendo, nuestros hijos sí!".

Entre abril y junio del 2018 volví al distrito de El Cenepa. Mi objetivo era pensar junto a Jorge, otros jóvenes y sus familias, las experiencias awajún de vivir con VIH o SIDA. Durante mi trabajo de campo, me quedó claro que las ideas biomédicas sobre la diferencia entre VIH y SIDA, como dos momentos serológicos diferenciados por la carga viral, no era algo central en el pensamiento awajún. Ellos tenían otros criterios para pensar los diversos malestares que los afligían. Por ello, en este artículo, propongo aproximarme a las experiencias y conceptos awajún que se entretejen en su uso de las palabras "VIH" y "SIDA". Estas palabras biomédicas fueron insertas por los Awajún dentro de sus concepciones de játa, una palabra que ellos traducen al castellano como "enfermedad" o "muerte", y de waweamu, una palabra que ellos traducen como "daño" o "brujería". De esta manera, los Awajún han creado nuevas expresiones como "játa SIDA" y "waweamu con síntoma de SIDA", que juntan palabras apách a palabras awajún para referirse a sus propias experiencias de enfermedad y de daño asociadas al VIH/SIDA. 
Durante mi trabajo de campo, el concepto de virus no se presentó como algo central para las familias awajún. Por ello, mi estudio no se enfocó en los factores que contribuyen a la propagación de esta condición viral. Tomando distancia de los abordajes de corte epidemiológico, me concentré en las perspectivas awajún expresadas en sus propios términos, a través de sus comportamientos y las narraciones de sus experiencias sobre sus padecimientos. Las familias awajún que me acogieron fueron el foco principal de mi trabajo de campo, especialmente las madres que me permitieron acompañarlas en sus actividades diarias en la cocina, la chacra, el cuidado de sus hijos y el comercio. Espero retratar correctamente los conocimientos que me brindaron generosamente. Para mantener el anonimato de mis interlocutores he cambiado sus nombres personales y familiares. Asimismo, no hago mención del nombre de las comunidades en las que desarrollé mi estudio.

Desde el 2005 se han diagnosticado 210 personas awajún con VIH/ SIDA en el distrito de El Cenepa (Ver gráfico 1). Sin embargo, la información oficial del sector salud es inconsistente en el número de diagnósticos y no distingue los casos de VIH y de SIDA. Por ello, fue necesario consultar tres fuentes: el reporte de la Red de Salud Condorcanqui (2018); la información publicada de la Microred de Salud Huampami (2018) y los datos distritales levantados por Pintado (2016).

Reporte de casos VIH positivos en el Distrito de El Cenepa (2005 - Junio 2018)

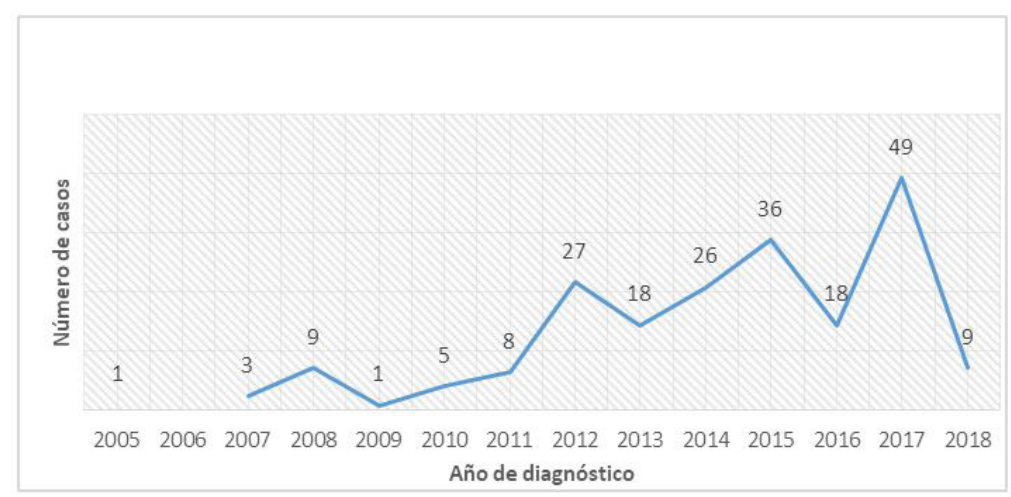

Fuente: Elaboración propia. 
Los recientes estudios de VIH/SIDA en población indígena amazónica indican una incidencia alarmante en diferentes países de Latinoamérica. Ese es el caso de los Warao de Venezuela, los Xokléng de Brasil, los Shuar de Ecuador, los Embera Chamí de Colombia, los Chamococos de Paragua, los Guna de Panamá, y los Shipibo-Conibo, Awajún y Wampis del Perú (SIPIA \& ONUSIDA 2016). Sin embargo, hay pocos estudios antropológicos sobre el tema. La mayoría de los estudios son epidemiológicos y suelen coincidir en la identificación de factores de riesgo contrastado las prácticas indígenas de salud con los conocimientos biomédicos del VIH/SIDA. Estos son algunos de los factores subrayados: el contacto con las ciudades, la presencia de actividades extractivas, la migración, el limitado acceso a servicios de salud, el desplazamiento forzado, los procesos de aculturación y el contacto con fuerzas militares. Dichos factores están asociados a aspectos socioculturales propios de cada pueblo y a la pobreza estructural y/o violencia que identifican algunos estudios (Farmer \& Castro 2005).

A esta evaluación de factores externos, se suman la identificación de riesgos internos que son definidos como comportamientos "culturalmente peligrosos" o falta de conocimientos asumidos como inherentes a la condición indígena. Esta premisa ve a las "costumbres indígenas" como limitantes para la adopción de técnicas y tratamientos biomédicos. Los estudios realizados con población indígena peruana (Orellana et al 2013; Orellana \& Alva 2012; MINSA \& UNFPA 2009; Zavaleta et al 2007) subrayan: el uso de plantas medicinales, el limitado uso de preservativos, el inicio sexual a temprana edad, el sexo transaccional y el homoerotismo como factores culturales que tornan a los indígenas más vulnerables. Estos estudios colocan a la noción de cultura como algo fijo y ligado a lo indígena. Sus "comportamientos de riesgo" hacen a los indígenas culpables de las epidemias y nublan las discusiones sobre sus experiencias, demandas y los limitados servicios de salud presentes en cada uno de los contextos.

En el caso de la población awajún del Perú, los estudios sobre VIH tienen por objetivo hacer propuestas de políticas públicas. Pintado (2016) discute la incorporación del Tratamiento Antirretroviral (TARGA) en el distrito de El Cenepa; Huamán, Gushikuen, Benites, Quiroz \& García (2017) abordan las barreras que limitan el cumplimiento de las medidas de prevención de la transmisión materno-infantil del VIH y Lazo (2014) presenta una propuesta de modificación de la Norma Técnica de Salud para la atención del VIH en la población awajún. Sin embargo, este autor también subraya la necesidad de abordar el VIH/SIDA a partir de las concepciones indígenas. 
Mi estudio se distancia de los enfoques epidemiológicos que ven a la "cultura local" como un problema y enfoca la necesidad de abordar la percepción awajún de las enfermedades traídas por la colonización para lograr comprender sus actitudes ante la actual epidemia de VIH/SIDA. En este artículo, presento el caso de dos jóvenes varones que nos permiten acceder a la experiencia vivida de esta condición y, especialmente, al protagonismo de las madres awajún en sus esfuerzos por devolverles la vida.

\section{La enfermedad como experiencia}

En este artículo sigo la línea de la antropología de la salud que aborda la enfermedad como experiencia a partir de los aportes de Kleinsman (1978). Según este autor, la "enfermedad" (traducción del concepto inglés de "sickness") es un proceso amplio de experiencia vivida que tiene como protagonista al sujeto, no solo desde una dimensión biológica sino, como sustenta Menéndez (2015), integrado en procesos sociales, políticos, económicos y cosmológicos. Como enfatiza Alves (1993), los episodios de enfermedad son momentos por medio de los cuales las personas y las colectividades generan interpretaciones de sus vivencias, transformándolas en impresiones sensibles que integran a sus nociones de enfermedad (Alves en Agostini et al 2018: 204).

El trabajo de Langdon $(2001 ; 2014)$ con el pueblo Siona fue central para el desarrollo de la antropología de la salud en la etnología. La autora muestra que la enfermedad es un proceso sociocultural de experiencias y percepciones subjetivas y colectivas, a partir de las cuales las personas interpretan los síntomas, identifican las causas y aplican tratamientos que tienen efectos en múltiples registros corporales y sociales. Estas propuestas de la antropología de la salud dialogan con los aportes de Seeger, Da Matta y Viveiros de Castro (1979) sobre el cuerpo amazónico como matriz social y las etnografías que destacan el lugar de la alimentación y el resguardo en la producción, transformación y generificación de las personas (Belaunde 2001; 2003). El trabajo de McCallum (1998) sobre el cuerpo Huni Kuin es aquí un aporte resaltante. La antropóloga presenta los procesos de producción y la agencialidad de las "personas verdaderas" para entender los procesos de enfermedad indígena. Las personas verdaderas generificadas "hacen saber", "hacen conocer" y pueden curar los cuerpos de otras personas verdaderas, movilizando múltiples dimensiones no dicotómicas de materialidad, sociabilidad y espiritualidad. A partir de estos trabajos propongo aproximarme al cuerpo amazónico enfermo en su multiplicidad, conformado por pliegues de relaciones con otros seres humanos y no humanos. 
Siguiendo las propuestas de Overing \& Passes (2000), Gow (1989), McCallum (1998) y Belaunde (2001), considero el cuerpo como una malla relacional producida en relación con otros sujetos, substancias, espíritus y fuerzas vitales que son manejadas durante los ciclos de vida por las familias. En particular, a partir de estos autores, enfoco las relaciones de convivencia cotidiana y ritual que sustentan la producción de parientes y la crianza de los hijos de ambos géneros como procesos de experiencia vivida y de adquisición de capacidades productivas, de pensamiento, de memoria y de cuidados. Como ha sido demostrado por estos autores, el cuidado de los hijos es uno de los ejes principales de la socialidad amazónica y de sus prácticas terapéuticas. Es a partir de esta experiencia de convivencia, que se teje por la red de parientes, que deseo pensar la agencialidad de las madres awajún y sus esfuerzos para cuidar y devolver la salud a sus hijos.

Según Kopenawa \& Albert (2015), en la cosmovisión yanomami, la esposa del demiurgo Omama, mujer de las aguas, luego de procrear a los Yanomami solicitó la creación de los xapirí, seres que los protegen de la muerte y de las enfermedades: "Criei os xapiri, para curarem nossos filhos!" (Ibid.84). Esta agencialidad de las madres y la preocupación cosmológica y cotidiana con la salud de los hijos también fue observada en otros casos etnográficos. Los aportes de Belaunde (2001) en el caso Airo-Pai, McCallum (1998) con los Huni Kuin, y Pina de Barros (2000) con los Bakairi, muestran el papel central de las madres para la salud de los hijos. Las madres proveen cuidados y terapias a sus hijos por medio de la alimentación y el uso de plantas. Les aplican ungüentos, enemas y cremas; regulan las entradas y salidos de sus fluidos; y controlan posibles relaciones de peligro para preservar la vida de sus hijos. Asimismo, como muestran Kelly (2003) y Langdon (2014), con la llegada de los sistemas médicos no indígenas (del Estado y/o de las Misiones), las madres indígenas establecen relaciones con estas nuevas ofertas de salud para asegurar el cuidado de sus familias frente a las nuevas enfermedades traídas por la colonización. Ellas llevan a sus hijos a los nuevos servicios biomédicos, negocian con sus especialistas y deciden sobre futuras atenciones.

La interacción entre los servicios de salud biomédicos y los conocimientos de salud de la población indígena es un tema que ha sido desarrollado por Albert \& Goodwin (1997), Buchillet (2004), Diehl \& Grassi (2010), Garnelo \& Buchillet (2006) y Kelly $(2003 ; 2010)$. En su estudio sobre los yanomami, este último autor, propone una metodología de investigación "de punta a punta" enfocada en la interrelación de las perspectivas yanomami sobre los blancos y las perspectivas de los blancos sobre los indígenas. Según Kelly, los puestos de salud, y los servicios que aquí se prestan, son activos sociales en la cotidianidad de las comunidades yanomami y lugares donde confluyen y chocan diferentes concepciones del mundo, generando "equívocos". 
El concepto de "equívoco" propuesto por Viveiros de Castro (2004) no se refiere a un error de comprensión. Según este autor, el equívoco "is a failure to understand that understandings are necessarily not the same" (Ibid. 11). El perspectivismo indígena está plagado de conceptos homónimos, por ello la comunicación entre perspectivas se da siempre por medio de una traducción que demuestra la existencia de los diferentes sistemas de referencia. Kelly (2010) considera esta noción de "equívoco" fructífera para entender los encuentros entre los chamanes yanomami y las políticas de salud del Estado venezolano. "El mundo de las cosas y eventos es, en realidad, un mundo de homónimos y acciones" (Ibid. 288). Algunas veces las personas en interacción tienen conciencia de estos distintos sistemas de referencia y los "equívocos" en su comunicación son controlados. Pero otras veces, la falta de conciencia de la homonimia crea sistemas univócales que se creen compartidos a todas las perspectivas posible (Ibid. 289). La identificación de estos equívocos "controlados" y "no controlados" son para Kelly, centrales para entender la interrelación y tención entre los sistemas de salud "indígena" y "occidental". Su argumento también es válido en el caso del pueblo awajún y la actual epidemia de VIH/SIDA. Las actividades de los agentes de salud peruanos y sus relaciones con la población awajún están atravesadas por múltiples "equívocos no controlados". Por ejemplo, los Awajún y los agentes de salud tienen diferentes entendimientos sobre la importancia de mantener la confidencialidad de los diagnósticos; sobre los motivos que llevan a interrumpir el tratamiento antirretroviral; y sobre la culpabilización de la población awajún por el personal de salud debido a sus "creencias de brujería". En este artículo, debido a restricciones de espacio no examinaré en profundidad estos equívocos, pero es importante mencionarlos para contextualizar la heterogeneidad de experiencias de VIH/ SIDA que me propongo presentar.

Como sugiere Margulies, Barber y Recoder (2006: 288), los enfoques biomédicos suelen presentar a la persona como huésped de su enfermedad y tornar a su experiencia algo secundario. Desde la mirada del personal de los servicios de salud el cuerpo del enfermo es tornado objeto, se le quita lo social dando énfasis a su aspecto biológico. Ello se construye dentro de la dicotomía de naturaleza y cultura que no corresponde a la perspectiva indígena. Mi intención es enfocarme en las experiencias de las personas afectadas, de las familias y, en particular, de las madres. Sigo los lineamientos teóricos esbozados en esta sección para explorar las nociones y experiencias awajún que se tejen en torno al VIH/SIDA. 


\section{Játa atsú y la llegada de los apách}

Para conocer la perspectiva awajún sobre el VIH/SIDA, recogí las memorias de los ancianos sobre las epidemias pasadas. La palabra "játa", derivada del término awajún "ját(a)", traducida en castellano como "enfermedad" o "muerte", era usada para referirse a todo tipo de malestar en el cuerpo de una persona. Su uso polisémico estaba asociado al recuerdo de las epidemias venidas con los primeros apách ${ }^{3}$ (colonos y misioneros) que ingresaron al distrito de El Cenepa en el siglo XX. Estos apách llegaron con enfermedades contra las cuales, los Awajún no estaban preparados inmunológicamente dándole fin al periodo recordado como "játa atsú", es decir, el tiempo en que "no había enfermedad". Como explicó el abuelo Kumpam:

"Antes, "játa atsú", no había enfermedad. Vivíamos sanitos. Las mujercitas preparaban masato (bebida de yuca) he invitaban. Venían de otras casas y celebraban. Antes no había doctores, no había enfermedad.

iPara todos los dolores con nuestra planta no más! Antes nosotros curábamos así. iNo sé qué enfermedad será! iAntes si funcionaba, pero ahora no! Antiguamente los viejitos como nosotros, ahora muertos, explicaron a nuestras madres; y ahí, nosotros comenzamos a saber. Antes, cuando estaba mal un familiar, les explicaban a sus familias: 'esa planta está buena, así tienes que curar'. Así nos curábamos"

Según los abuelos, el tiempo de enfermedad se inició con el secuestro de jóvenes awajún por los misioneros, quienes los raptaron con el objetivo de enseñarles el idioma castellano y convertirlos en mediadores de la recepción pacífica de la misión. Este secuestro es recordado como el evento que "destruyó" la vida de algunos jóvenes.

Un día los pastores cogen a un niño de un grupo que estaba bañándose y ese hijo lo llevan a su país para enseñarle el idioma y lo destruyen. Lo llevaron de 12 años, con 20 años lo devuelven. Lo dejaron en el mismo sitio, diciéndole: 'Convérsalo bien'. (Muun Rubén, 2018).

En 1929 llegó la primera misión al territorio awajún a cargo de la Iglesia Evangélica Nazarena y en 1935 se fundó la primera escuela (Riol 2015). A partir de 1940, los jesuitas también introdujeron escuelas que dinamizaron el desplazamiento de la población y el asentamiento de las familias alrededor de las escuelas, así como la migración de los jóvenes indígenas a ciudades 
cercanas para completar su educación. La expectativa de dominar la lengua castellana alentaba al pueblo awajún: "El pueblo escuchaba que el hijo de Dantucho ahora era profesor, ya es civilizado. iQuién no va a querer! Desde aquí remando llevaban a sus hijos que estudien" (Muun Kumpam, 2018).

La educación impulsada por las misiones evangélicas y católicas fue aceptada por la población awajún como contraparte de su deseo de acceder a los bienes de los blancos, en particular, al dinero. Por ejemplo, en los primeros años de la misión Nazarena, los cheques de banco del pastor Winans eran atractivos para los Awajún. Ellos querían conocer "los misterios del papel": "A mi regreso, un grupo de indios querían ver mi libro. Me explicaron que se trataba de una página que era suficiente para adquirir toda una carga de mercancías y un puñado de monedas. Les mostré mi chequera." (Winans 1989 en Riol 2015: 271). La oferta de educación, los bienes materia les y el dinero fueron la bandera de civilización de las misiones. La población awajún se adhirió a ella como estrategia para asegurar su existencia, que había sido amenazada por intentos previos de conquista y esclavización. Como argumenta Vilaça (2006:30) en el caso de los Wari, frente al peligro de exterminio de la colonización, la población indígena decide reconstruir su propia sociedad a partir de la invasión de su territorio.

Sin embargo, la presencia misionera también generó revueltas en el distrito de El Cenepa. Es especialmente recordado un enfrentamiento en la década de 1940, cuando la población percibió que con la llegada de los apách llegó también el "contagio" de enfermedades. Por ello decidieron matar a un sacerdote y expulsar a las misiones.

"El pueblo dijo: 'Ellos traen tifoidea, sarampión, otras enfermedades que nosotros nunca hemos probado. Éramos sanos y ellos que vinieron nos quisieron contagiar. Ahí viene uno de ellos, un cura'. El pueblo se organiza y lo mata'". (Dante, 2018)

El sarampión fue la enfermedad que más afectó a las familias awajún entre las décadas de 1940 y 1950. Así lo narró un sobreviviente:

“iEnfermedad fuerte! Sarampión. Mató a 7 ahí (en su casa en la quebrada Pumpu), con dolor de ojo, heriditas en la piel. Enfermó a los niños y adultos. Ahí murió mi hermano, mi papá, mi mamá. iTodos! Solo quedé yo, mi hermano y mi hermanita. Ella se fue a trabajar a Nieva y se contagió también".-

Los comerciantes, misioneros y profesores fueron, en consecuencia, vistos como vectores de transmisión de enfermedades como la viruela, el sarampión, la fiebre amarilla y la "gripe de gringo". 
“Gringo, alemán creo. Ellos llegaban a comprar. Vinieron 5, 10; sus esposas también llegaban. No se quedaban mucho tiempo. Venían, pasaban y se iban.

iCuando llegaban no sé qué enfermedad traían, de ahí todos enfermaban!" (Muun Santiago, 2018)

Como en otros lugares de la Amazonía, la llegada de los apách, de la "palabra de Dios", de la escolarización y la idea de "progreso" vino acompañada de una conquista epidemiológica o "guerra biológica" (Buchillet 2004; Garnelo \& Buchillet 2006) que colocó en riesgo de exterminio a la población awajún. En las memorias de los abuelos awajún, esta supuesta integración de la población indígena a la ciudadanía peruana fue el final del tiempo saludable del játa atsú. La colonización y la introducción del cristianismo, como identifica Vilaça (2008) en el caso Wari, acarrearon una metamorfosis del cuerpo indígena debido a la adquisición de nuevas perspectivas y condiciones de "origen enemiga". En la actualidad, dicha metamorfosis continúa debido a la llegada de las iglesias evangélicas, que influencian nuevas nociones de cuerpo, de salud, de peligro y de pecado.

El fin del játa atsú y el inicio de las enfermedades, por tanto, condujo a la adquisición de nuevos conocimientos y a la introducción de los servicios de salud apách en la población awajún. No es mi intención enfocar este tema en este artículo, pero señalo que, en 1983, con el impulso del Consejo Aguaruna Huambisa, se formó a la primera generación de técnicos sanitarios awajún. Estos especialistas con conocimientos biomédicos trabajaron de forma gratuita en sus comunidades hasta 1993, cuando el Estado peruano reconoció las boticas comunitarias como Puestos de Salud. Estas prácticas biomédicas coexisten con una gran variedad de prácticas curativas indígenas y no biomédicas provenientes de otros pueblos vecinos de la región.

Mientras la noción de játa está asociada al periodo histórico de la colonización, la noción de waweamu, es decir, de "daño" o "brujería", es concebida como un aspecto inherente de las relaciones entre indígenas desde el pasado. Durante mi periodo de campo se hablaba de la existencia de cuatro tipos de especialistas asociados a la posibilidad de aliviar malestares o de curar el waweamu: los tunchis (brujos con poder de hacer daño y de curar daños causados por otros tunchis mediante rituales chamánicos), los curanderos (brujos "buenos" que dicen no ser tunchis para no ser vistos como peligrosos y que practicaban básicamente las mismas curas chamánica que estos), los herbaleros (especialistas que curaban las enfermedades con plantas) y los "doctorcitos" de las plantas (seres "como humanos" a lo que se accedía por medio del consumo del toé o ayahuasca). Estos cuatro especialistas aseguraban el cuidado en las dimensiones físicas (iyásh) y espirituales (wakán) del cuerpo awajún. 
Las enfermedades traídas por los apách han creado nuevos repertorios de cura y estas, a su vez, han generado nuevas formas de daño. Por tanto, existe una interrelación entre los cambios históricos que afectan las nociones awajún de játa y de waweamu, y en consecuencias, sus prácticas chamánicas y curativas. Como argumenta Pérez-Gil (2001) los sistemas chamánicos de los pueblos amazónicos son representaciones colectivas y sus especialistas poseen una capacidad creativa que se actualiza en los nuevos contextos. El trabajo de Buchillet (2004) identifica muy bien estas actualizaciones y resalta, en el caso de los especialistas Kumu del pueblo Desana, una regla central: "to cure a specific illness you have to know how to provoke it" (Ibid. 123). Ese argumento parece también aplicarse a la actualización de los brujos y otros especialistas de la salud awajún. Con la llegada de nuevas enfermedades apách, surgieron también nuevas formas de hacer daño.

"Antes no creíamos en enfermedad solo en brujería. Ahora otros malos brujos dan también (la enfermedad)" (Simón, 2018).

\section{Concepciones awajún sobre VIH/SIDA}

Las palabras apách "VIH" y "SIDA" han sido insertas por los Awajún dentro de sus concepciones de játa o/y waweamu". Así, los Awajún han creado nuevas expresiones: "játa SIDA", y "waweamu con síntoma de SIDA" para denominar sus propias experiencias de enfermedad o daño asociados al VIH/ SIDA. La palabra "síntoma" también ha sido integrada en sus concepciones y es usada para referirse a los signos asociados a la enfermedad o al daño de "VIH" y "SIDA". Durante mi trabajo de campo, los "síntomas del SIDA" usualmente mencionados eran: enflaquecimiento, "intashi uwegu" (caída de cabello), "tseweu" (fiebre), "nampichiaanin minitu dekapeu" (una lombriz atracada en el cuello), "muun iyaan jegkemjuku wakeg" (barriga dura e hinchada), "wakeenajemamu" (dolor de estómago), "kuwin amau" (heridas en todo el cuerpo), "achiku numchip" (heridas en la garganta y boca), "akape tajaku" (el hígado "se hincha y baja") y "buuk najamu" (dolor de cabeza).

Es resaltante la ausencia de la palabra "virus" en las descripciones de las personas; así como también llama la atención la referencia a la posición de los órganos, a su textura y a la sensorialidad que tienen de ellos. Este es un claro ejemplo de un "equívoco no controlado" que surge en este contexto. Lo que para el punto de vista biomédico era una epidemia causada por un virus, desde el punto de vista awajún era, en parte, un movimiento de descontrol de las prácticas sexuales y de las actividades de brujería entre awajún. 
Foto 1: Dibujo de los órganos afectador por el "Síntoma de SIDA"

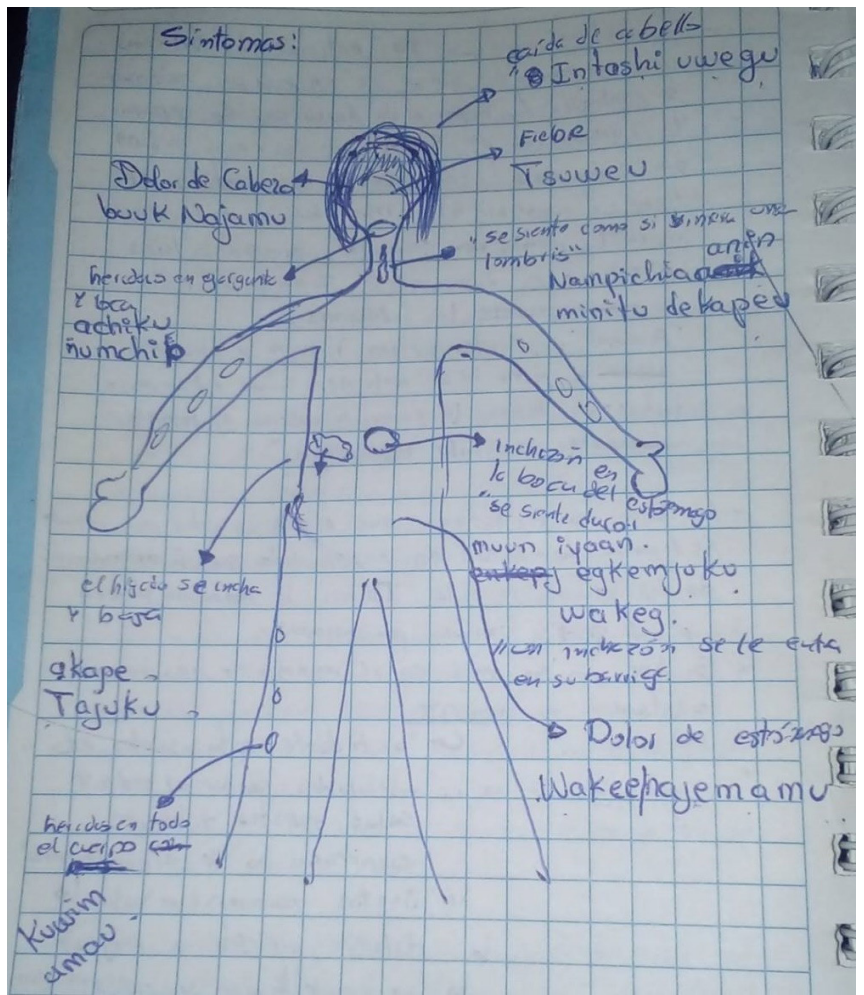

Fuente: Familia Túwi, 2014

\section{“Játa SIDA"}

La noción "játa SIDA" es usada por las familias awajún para referirse a la enfermedad del VIH o SIDA detectado en el puesto de salud, por medio de pruebas rápidas de sangre. En los últimos años, las expresiones "enfermedad de VIH", "játa VIH-SIDA" y "setash"4 se han diversificado; sin embargo, "játa SIDA" fue la expresión que escuché recurrentemente en las comunidades que visité. Lo central de estas expresiones es su asociación al lenguaje de los establecimientos de salud pública ${ }^{5}$.

El "játa SIDA", traducido como "enfermedad del SIDA", según la población awajún, es un padecimiento transmitido por relaciones sexuales con el que una persona puede vivir muchos años después de haber sido diagnosticado. A condición de seguir su tratamiento: "iDicen que puedes vivir 5, 10 años, no te mueres con eso! Tiene su tratamiento"; Esta frase se refiere a los antirretrovirales, también llamados por los Awajún como "pastillas" (en castellano), "ampi" (en awajún) o, incluso, "ampi játa SIDA". 
El propio personal de salud también ha adoptado estos términos. Por ejemplo, en una comunidad, el puesto de salud tiene pintado un mural que da la bienvenida a los pacientes con este mensaje:

"Játa VIH-SIDA. tawaduka, tsagaushta ya! Tuyash Ampiji Ajawai"

"La enfermedad VIH-SIDA. Eso lo que dicen no sana iPero tiene su pastilla!"

La sangre tiene un protagonismo especial en los casos de "játa SIDA". Los jóvenes en la escuela suelen comentar que su "sangre está buena" cuando no les detectaron VIH en el puesto de salud. Asimismo, repiten las recomendaciones del puesto de salud sobre los posibles medios de transmisión a través de la sangre. Antiguamente, la proximidad a una persona con "játa SIDA" causaba temor. Las familias dudaban en compartir cubiertos, cobijas y ropa por temor a la transmisión de esta enfermedad. Este panorama ha cambiado, actualmente las personas hacen referencia casi únicamente al peligro de las relaciones sexuales y al contacto con algunos fluidos (en especial la sangre y leche materna). Las madres seropositivas en muchos casos dejan de lactar a sus hijos para evitar un posible contagio y en las comunidades, se comenta, que de preferencia los esposos o parientes cercanos lavan con cuidado la ropa de los miembros enfermos.

\section{“Waweamu con síntoma de SIDA”}

Las expresiones "waweamu con síntoma de SIDA" y "daño con síntoma de SIDA", se refieren a la sospecha de ser víctima de brujería. Algunas familias también usaron la expresión de "Sidajai besét waweamu", asociado a la muerte de una persona por daño con enfermedad de VIH o SIDA. Según el pensamiento y la práctica awajún, una persona puede ser afectada en sus pliegues físicos y espirituales al ser atravesada por dardos invisibles, denominados en awajún "tséntsak", que son enviados de la boca de los tunchis o "brujos" de forma deliberada. Estos brujos tienen la capacidad de:

1. crear los tséntsak o dardos de daño con "VIH" o "SIDA" para mandarlos a sus enemigos;

2. causar "falsos positivos" en el puesto de salud, es decir, hacer que el resultado del tamizaje aparezca como positivo cuando realmente la persona no tiene esta enfermedad; y

3. empeorar la condición de la persona que ha sido diagnosticada con "játa SIDA" en el puesto de salud, haciendo que esta no mejore e incluso muera. 
El "waweamu con síntoma de SIDA" no es una enfermedad que puede ser diagnosticada en el puesto de salud ni ser tratada únicamente con pastillas. Para tratarla se requiere la intervención ritual del uso de plantas aliadas y la movilización de ámbitos cosmológicos, que permitan restaurar los pliegues físicos y el alma del cuerpo awajún. Una persona con waweamu al ser víctima de un daño dirigido no puede transmitir la enfermedad que el tséntsak le causó, pues realmente es un daño enmascarado. Únicamente en el tercer caso, donde la persona ya fue diagnosticada con "játa SIDA" y el tunchi la empeoró, se considera posible que mediante relaciones sexuales esta pueda transmitir su condición de "játa SIDA" a otras personas.

\section{Dos trayectorias de padecimientos}

Los Awajún enfrentan diariamente la posibilidad de ser afectados por enfermedades o dardos de daño. Ambas condiciones, como veremos a continuación, no son mutuamente excluyentes. La historia de Elvis y de Ricardo son ejemplos de la coexistencia porosa de estas experiencias que se hacen complejas con la llegada del VIH/SIDA.

\section{La lucha de Elvis}

Conocí a los esposos Túwi (el señor Dante y la señora Tania) en el 2014 y durante el 2018 tuve la suerte de residir en su casa. Una tarde mientras la señora Tania cocía me mostró la foto de Elvis: "Mira es mi hijito, Elvis. Él era un buen niño, un niño que ayudaba a su mamá. iSiempre me ayudaba! Cuando no había nada, él me ayudaba". Esta foto de tamaño A4, protegida por una mica de plástico le dio rostro a una crónica familiar de daño y sospecha de VIH/SIDA que se me presentó desde de la memoria de su madre.

Después de terminar la escuela, con aproximadamente 20 años, Elvis fue mandado a dos ciudades cercanas para convertirse en "chef". "Sabía cocinar de todo y itodo lo hacía bien! Terminó su (cuarto) ciclo y volvió. En ese entonces (la casa) tenía un solo piso con paredes de madera y techo de yarina (Phytelephas macrocarpa). Ahí hizo su restaurante". El éxito del negocio fue inmediato, "los que pasaban de Nieva venían, los que trabajaban aquí venían, irico cocinaba!". Así, Elvis decidió expandirse y vender cerveza en este local, "tenía quince cajas de cerveza y caña". En las comunidades de frontera este capital es apreciado porque el precio de reventa de la cerveza es el doble que en las ciudades. 
Este camino de prosperidad fue interrumpido cuando Elvis comenzó a sentir malestares recurrentes que, según su madre, se iniciaron con la incapacidad de comer:

"En la garganta sentía algo y no le dejaba pasar. Como si algo estuviera ahí atracando, icomo una lombriz! Yo quería sacarlo, pero no podía. Elvis no podía tomar agua, no podía comer, vomitaba, a veces también tenía dolor de cabeza y fiebre. Su estómago se le hinchó y se le hizo duro".

La Señora Tania trató de revertir esta condición: "Yo lo comencé a tratar con plantas y medicinas, pero el dolor lo mantenía en la barriga. Tenía fiebre. iTraté mucho! Pero no se recuperaba. Así lo llevé a Puerto D. donde mi cuñado para que le dé ayahuasca".

Ante la falta de mejoría los esposos Túwi decidieron llevar a su hijo a una comunidad vecina en busca de su primer diagnóstico, consultando a un cuñado que sabía llamar correctamente al espíritu de la planta. Como me comentaron los esposos Túwi, el ayahuasca (Banisteriopsis caapi) es una planta que "mira" y "cura todo". Para que tenga este efecto, es importante que la persona enferma y el "guía", o ayahuasquero, hagan previamente una dieta, alejándose de los olores que desagradan a la planta. El ayahuasquero debe abstenerse de comer alimentos grasosos, dulces, carnes rojas y bebidas alcohólicas. También debe evitar estar cerca a mujeres embarazadas, tener relaciones sexuales e incluso estar próximo a personas que hayan tenido relaciones sexuales recientemente. Solo cumpliendo estas restricciones, el especialista puede preparar el brebaje de ayahuasca, que es ofrecido al enfermo durante una sesión nocturna. El ayahuasquero da de beber al paciente y los presentes esperan alrededor de su pariente a que la planta se manifieste.

La llegada de una serpiente envolviendo el cuerpo de Elvis fue el inicio de la visión. La Señora Tania recuerda que Elvis le contó que el ayahuasca le mostró que él tenía waweamu; y le presentó a los responsables tal acto. Elvis narró a su madre la amenaza de muerte que recibió durante su visión. “Dos señores le dijeron: 'tú vas a morir siempre, te van a poner en el cementerio en un ataúd'. iEra waweamu!" Frente al temor de que Elvis piense tanto en este diagnóstico que de tanto "pensar, pensar se enferme" (una acción que hace agravar a algunos jóvenes awajún), su madre recuerda haberle aconsejado: "No pienses en eso hijito".

$\mathrm{Al}$ retornar a su comunidad, el diagnóstico de waweamu fue también confirmado por un curandero mediante nuevos métodos. "El curandero compró una cerveza, la destapó y en la espuma se formó un caballo. Ahí nos dijo: 'Esto es mágico, ese señor lo ha hecho. Dos señores han acordado para 
dañarlo a tu hijo. Han entrado a su tienda y cuando estaba tomando cerveza, iahí en el vaso le han dado el daño! "'. El curandero describió a detalle a los culpables y la familia reconstruyó los hechos del día en que el daño ocurrió.

"Mi hijo no sabía con quien había tomado y yo le hice acordar. Me dijo que, primero, llegó un señor sospechado de tunchi y, luego, ingreso otro señor aquí a mi casa, donde vendíamos cerveza. El segundo señor quería comprar pollo. Mi hijo salió a buscar el pollo y los dos se quedaron. Ahí, los dos conversaron y sobraron un poco de cerveza. Justo cuando vino mi hijo le dijeron que tome esa cerveza. Tomó. IJusto ahí se enfermó! El curandero le dijo: 'Tú no te ha dado cuenta, pero iel dolor empezó ahí! '”

La señora Tania, frente a esta segunda confirmación de daño, respondió con dietas estrictas para su hijo de "sopitas, comidas sin grasa, no patarashca, no guiso, no conservas, no frituras, no pescado frito, ni cervezas o gaseosas", para combatir la debilidad de su cuerpo.

El saberse dañado no excluyó la búsqueda de otros diagnósticos en el sistema de salud apách. En el 2013, con 24 años, Elvis fue al puesto de salud de su comunidad donde le diagnosticaron con "enfermedad de VIH". Su madre recuerda este diagnóstico y sus intentos para desenmarañar el sistema de salud apách; sin embargo, la poca información le causó más dudas.

“Mi hijo luego me dijo que estaba con enfermedad de VIH, que el doctor le había sacado sangre. Él me contó que le habían sacado bastante sangre esa primera vez.

Yo luego lo llevé al puesto de salud de $H$. Ahí le sacaron sangre y me dijeron que ya estaba sano. iLe dijeron que era negativo! Me contó que le habían dado solo preservativos, diciendo: 'tú eres bueno' y iya! Así lo dejaron.

Él me decía: ‘ iMamá!, sé que a otras personas si les daban consejería. A mí no'. Con eso, si él estuviera enfermo me podrían enseñar, decirme que tenía la enfermedad SIDA. Pero inunca me han dicho nada! Lo llevamos al centro de salud, pero ino sanó! iLe hicieron examen, le llevaron su sangre, pero a mí no me decían nada!"

Luego de esta visita al puesto de salud, Elvis siguió debilitándose. Su enfermedad se generó como un tiempo paralelo para la familia; un tiempo de sufrimiento abrasador que se recuerda en torno a todas las acciones emprendidas por sus padres. Elvis, echado en su cama con el cuerpo debilitado empezó, en palabras de su madre, "a no vivir". Su cuerpo se 
transformó en la responsabilidad colectiva de su familia, organizada en relaciones de cuidado. Esta existencia sostenida en base a relaciones fue central luego del besémat o sueño de presagio de muerte. La Señora Tania recuerda claramente ese sueño: "Una noche Elvis soñó que había unas arañas en su mosquitero, tuvo una visión de animales. iSabía que iba a morir! Pero, no quería. Decía: 'No quiero morir. Me han hecho daño' ".

Esta alerta llevó a los esposos Túwi a la búsqueda de un quinto diagnóstico con un brujo en otra comunidad. El tunchi les dijo: "Como tienes dinero con tu tienda, te han hecho daño. Pero ite vas a sanar! No te preocupes". La señora Tania recuerda vagamente que el tunchi chupó la enfermedad del cuerpo de Elvis, le dio de tomar un brebaje e invocó a sus espíritus aliados. Ella no quiso repetir las palabras hechas por el tunchi por miedo a invocar al iwanch (o "diablo"6).

Luego de este ritual, el tunchi anunció que Elvis ya estaba curado. Sin embargo, esa misma noche él empeoró. La señora Tania recuerda que Elvis le dijo: "iTal vez el brujo me ha brujeado más!". Luego del reclamo de los esposos, el tunchi adjudicó el malestar a una tifoidea. Les recetó medicamentos y les indicó volver a su comunidad, pero les advirtió no volver a la casa donde residían. "Nos dijo: 'Llévenlo a su casa, pero no donde viven ahora. iEso está dañado! Llévenlo a otro lado. La persona que le puso daño a Elvis le puso también a la casa. Les está molestando, itu hijo va a morir si vuelve ahí!' ".

Los dardos de daño alojados en la casa de los Túwi motivaron la salida de la señora Tania y de sus hijos menores de su comunidad. El nuevo espacio de cuidado se dispuso en una casa ubicada en una chacra cercana. Así lo recuerda la Señora Tania:

“Fuimos entonces a una casa de mis cuñadas. Estábamos todos $N, B, C$ pequeño y también A. Nosotros en el suelo nos acomodamos. Mi hijo estaba en la cama. En el día, le cocinaba su sopita, le cuidaba. iYo le ayudaba a hacer todo! A sus heces, a que coma. A todo a mi hijito".

Pese a sus intentos, la continua debilidad de Elvis mostró a su madre que él no mejoraría. "Él ino se mejoraba! Le dio diarrea, orinaba y olía ifuerte! Ya ni fuerzas tenía para moverse. Así que le dije a mi hija que busque a su papá para que lo lleváramos de vuelta a la casa".

"Lo traje a la casa. Tenía el hígado iduro! Dolor de estómago. Le daba fiebre bien fuerte. Le compraba metamizol eso le mejoraba, pero recaía. iNo podía pasar, tenía algo en la garganta! Otra vez volvió a estar mal y nunca más se volvió a sanar. 
El puesto de salud vino, decían que le iban a sacar sangre para mandar a Lima. Pero iYa le había sacado 6 veces y nunca nos dieron los resultados!, i6 veces! Yo les boté, diciendo: 'iUstedes nunca me han dicho qué es, saca y saca y nada! No le van a sacar ahora sangre '.

Luego un día Elvis dijo: ' Mamá, no voy a recuperar y me quiero arrepentir, quiero estar con Dios. Llama al pastor '. Fui a llamarlo, pero tenía un curso, no venía. Llamaba al pastor diario. Elvis me pedía: ' iMamá, por favor, llámale! ‘. El día que el pastor iba a venir, con las pocas fuerzas que tenía, luchó con su dolor y se bañó. Su hermana lo ayudó a cambiarse. Llegó el pastor, todos nos arrodillamos, nos pusimos a rezar.

Después de eso mi hijito decía: 'iYa me siento mejor mamá, creo que me voy a mejorar! '. De ahí me dice que quiere ir al baño. Lo llevamos al baño con su papá y salió como diarrea ifuerte! y luego sangre nueva iviva! Mi hijo decía: 'antes no dejaría que me vieras así, me daría vergüenza. Ahora me limpias tú mamá '. Con eso se debilitó. No podía caminar. Su cuerpo quedó quieto.

Le llevamos de nuevo a su cama. Su papá fue a comprarle suero, le pusimos porque no comía. Pero él solito ya no quería: ‘ Mamá yo no voy a resucitar. Ya sácame el suero. iYa me voy a ir, me han hecho daño!' Se sacó la vía y se puso a dormir vestidito en su cama. Vinieron mis cuñadas para acompañarnos. Yo lloraba por él. Ahí a las 7 le preguntaba si estaba bien, me decía iSí! A las 8 ya no contestaba. Ya no hablaba. Ya sabía que iba a morir. No reconocía.

A las 10 de la noche se murió. Su último respiro ibien fuerte! y ahí se fue."

A las 11, los Túwi fueron a cenar a una casa vecina. "Lo dejamos a él solito con velas". Al volver, la familia vio en el cuerpo de Elvis la confirmación del waweamu. "Cuando volvimos a la casa, mi hermano tenía el cuello morado, estaba hinchado y se movía hasta acá (apunta los hombros)". El cuello dislocado y de color morado fue la evidencia post-mortem que Elvis había sido dañado. El tséntsak de daño luego de causarle la muerte había salido como una chispa de su cuerpo, "destrozándolo".

“iEstaba así morado! Por eso pensamos que deben haber hecho waweamu. iEso siempre pasa! El tséntsak tiene que salir. Cuando sale, deja destrozado el cuerpo. A veces también deja su mano bien amarilla iAsí pasa! Tomando toé eso vemos. iSale como una chispa, como electricidad! Así, sale el tséntsak». 
El cuerpo inerte de Elvis, su "iyásh" (cuerpo) sin "wakán" (alma/ espíritu), su "jakáu" (cadáver) fue envuelto de pies a cabeza con una sábana. $\mathrm{Su}$ cama fue rodeada de velas. La familia acompañó esa noche al uchi jakáu (o "hijo muerto"). Su padre preparó el cajón de madera para llevarlo al cementerio al día siguiente. Su ataúd fue llevado al espacio construido por la familia Túwi para sus miembros muertos. Lo colocaron al lado del ataúd de su abuela. Los Awajún no suelen enterrar a sus muertos dentro de la tierra, según me comentaron, esta práctica responde al deseo de algunas familias de abrir el ataúd un año después para observar los objetos de brujería introducidos en el cuerpo del pariente. El padre de Elvis selló el ataúd de su hijo con cientos de clavos, nunca se abrió.

La historia de Elvis se escribe y reescribe en la memoria de su familia. La señora Tania, mientras la narraba, comentaba también del miedo que sentía de que otro de sus hijos o hijas atraviesen ese mismo camino. El VIH/ SIDA era aún una incógnita para ella. Había perdido ya otros parientes con sospechas de "waweamu con síntoma de SIDA". Frente a estas dudas, la demanda al personal de salud por ser notificada sobre la salud de sus hijos era parte importante de sus memorias.

“Algunas mamás dicen que cuando sacan pruebas de sangre no nos avisan. No nos dicen que enfermedad tienen nuestros hijos. No dicen: “ itú tienes q dar este tratamiento! '.

Tantas veces pienso. A mi hijo le sacaron sangre 6 veces. iHa muerto mi hijo y nada! No hemos sabido ese resultado. iSin avisarnos nos llevan la sangre, lo mandan no sabemos a dónde! No nos dicen cuánto tiempo para esperar [el resultado] iEllos no nos avisan!

Cada persona tenemos responsabilidad ino? Cuando el doctor detecta SIDA, le puede decir a la madre: «Tú hijo se está enfermando con esto», y iYO lo cuido!”.

El daño en el cuerpo de Elvis y el diagnóstico hecho en el puesto de salud comparten una dimensión de secreto interesante. Tanto los dardos de daño lanzados por el tunchi como el envío de la sangre a Lima para confirmar su diagnóstico, por el personal de salud, son procesos que se hacen fuera de la vista de la persona afectada. Los especialistas médicos y los brujos inician caminos similares de diagnósticos y tratamientos que implican dimensiones similares de confidencialidad, de gestión del peligro y de acompañamiento a las que la persona y su familia enfrentan con desconfianza. 


\section{La vida de Ricardo}

En mayo del 2018 visité a Ricardo y le pregunté si es que me permitiría escribir su historia. Él rio y me invitó a pasar a la cocina de su madre. "Yo amo a mi comunidad, es donde viven mi familia, mis amigos", fue lo primero que dijo. "Me dicen cosas a veces, pero yo soy como soy iQué voy a hacer pues!".

"Desde los 14 años me di cuenta de que era diferente y me comencé a vestir de mujer. Me dejé el cabello largo y me vestía como una mujer. iA mí me gustaba, me sentía bien!

Pero mi mamá me decía: '¿jpor qué haces eso? Yo me voy a morir'. Mis hermanos, mis tíos se burlaban, murmuraban y eso no me gustaba. Mi papá dijo: ' imi hijo no puede ser así! ‘ "

A causa del rechazo, Ricardo decidió salir de su casa a los 17 años y fue acogido por Lorenzo; un amigo que le dio un espacio para dormir en la casa de sus padres. Este alejamiento de su familia terminó cuando su madre le pidió volver. iElla si me quiere!, por eso luchó para que vuelva".

“Ella me dijo: 'hijo por favor córtate el cabello. Ya no te vistas como mujer'. Entonces yo decidí cortarme el pelo. No quería que sufra. Me corté el cabello, regalé la ropa y dejar de vestirme, así como quería".

La tristeza de dejar de vestirse "como quería" fue transformada por él en un nuevo modo de ser "maricón" o "mariconcito": palabras dadas a los varones awajún que tienen una estética propia y que son reconocidos por entablar relaciones de enamoramiento exclusivamente con otros varones. Según me comentaron algunos señores, estos jóvenes antiguamente eran llamados de "shupánkau": término usado para referirse a los varones sin visión futura, que habían quebrado el resguardo durante su proceso de formación. La búsqueda de visión, denominada en awajún como "wainkamu"7, era un intento de los varones de vencer a la muerte por medio del consumo repetido de las plantas toé (Brugmansia suveolens) y/o ayahuasca (Banisteriopsis caapi). Para llegar a esta visión, los varones desde temprana edad debían respetar los resguardos de dietas y, especialmente, alejarse del olor de las mujeres que ahuyentaban al espíritu de las plantas. Según me explicaron, el "etse" o espíritu femenino que las mujeres tienen adentro, les hace oler muy fuerte. Si un hombre joven que estaba buscando visión sentía este olor, el "etse" femenino se le incorporaba y lo debilitaba; le quitaba la capacidad de visión e incluso le hacía adquirir el 
modo de ser femenino. "El hombre incorpora el etse de la mujer y se hace shupánkau". Los jóvenes con modo de ser femenino antiguamente no residían en las comunidades $y$, en algunos casos, eran castigados por reglamento con la toma de plantas para que "cambien su costumbre". Actualmente, con la llegada de la educación escolar, la búsqueda de visión realizada por los hijos varones ha dejado de ser central para los Awajún. La expulsión de sus jóvenes con modos de ser diferentes ha dejado de aplicarse; y la palabra "maricón" viene siendo asumida por ellos mismos ${ }^{8}$.

Ricardo se reintegró a su familia con quienes residía y compartía relaciones de reciprocidad y de cuidado. En especial desde su diagnóstico de "játa SIDA", del cual aún desconfiaba. Hace unos años, recuerda haber ido al puesto de salud luego de sentirse muy enfermo. "Tenía fiebre estaba bastante flaco, pensé que era tifoidea. Fui al puesto". Le tomaron una muestra de sangre y para su sorpresa le dijeron que tenía "la enfermedad". "Desde el 2010, 2013, que me dijeron. Ahí ya llevo como ocho años".

Luego de este primer diagnóstico, frente a la gravedad de su condición, sus padres (los esposos Uyush) decidieron recurrir a un reconocido herbalista de una comunidad vecina. Así lo recordaba Ricardo: "El señor W., me dio cuatro jarras de preparado de plantas con catahua (Hura crepitans 1.). Tomé, tomé y mientras eso, descansaba y vomitaba. iAsí mejoré!". La "leche" de la catahua (liquido blanco y viscoso) permitió a Ricardo hacer "sudar" su enfermedad. Luego de recuperar fuerzas, Ricardo y sus padres volvieron a su comunidad y acordaron con el herbalero una rutina de cuidado semanal durante un mes. "Él decía a qué hora comer, a qué hora tomar algo y dejó escrito la lista de las dietas que debía seguir." Este especialista visitaba la casa de los Uyush semanalmente para controlar los signos de debilidad, evaluar la excreción (de objetos y fluidos) y advertir posibles señales de peligro. Dependiendo de sus síntomas administraba también plantas o fármacos. Este tratamiento hizo que Ricardo volviera a comer, recuperara su peso y volviera a caminar.

La recuperación de Ricardo fue una noticia sorprendente para su comunidad. En el 2014, él fue la muestra para otras familias de que las plantas podían mejorar a una persona con diagnóstico de "játa SIDA". Incluso algunos jóvenes comentaban que luego de este tipo de cura, las personas con resultado positivo cambiaban sus resultados a negativo en nuevos diagnósticos de sangre. A Ricardo le incomodaban estos comentarios. Él no se definía como "portador" o "código"; expresiones que si usaban la comunidad y el personal de salud para referirse a él.

Ricardo reconocía tener malestares eventuales pero la idea de una enfermedad crónica le causaba dudas. "Bueno no sé si esta enfermedad así dura tanto o que será. Otras personas mueren a los 2 o 6 meses con eso de 
SIDA". La enfermedad awajún es principalmente sintomática y las muertes asociadas al "SIDA" le hacían dudar de su diagnóstico.

Frente a la llegada de cualquier malestar, Ricardo tomaba pastillas (recetadas para el dolor específico) y algún preparado de plantas. Junto a su madre recordaba ya haberse recuperado de enfermedades graves que les hicieron temer lo peor. "Estaba casi muerto" me decía su madre, quien lo acogía y cuidaba cada vez que Ricardo enfermaba. Ella tomaba el cuidado de su hijo en sus manos con la ayuda de su familia. Lo colocaba en una tarima de madera hecha en su cocina y lo acompañaba durante todo el tiempo de su enfermedad. La decisión sobre qué tratamientos, que dietas y qué especialistas consultar se hacía en conjunto. El camino preferido era buscar diagnósticos y medicamentos en una de las siete farmacias que había en su comunidad. Ricardo no quería ir al puesto de salud por temor de ser nuevamente recordado de su diagnóstico. Él comentaba: "no quiero ir al puesto, me van a decir de nuevo que tengo esa enfermedad".

Estas estrategias, desde el 2015, fueron acompañadas con el consumo itinerante del Tratamiento Antirretroviral (TARGA) dado gratuitamente por el puesto de salud de su comunidad. Ricardo fue uno de los primeros en ser incluido en este programa y pese a recibir mensualmente sus medicamentos afirmaba no tomarlos diariamente. "He seguido bien las pastillas, como 3 años. iPero me queda mal! Tomada de día y de noche, pero se cansa, por momentos se siente bien. Pero iel cuerpo queda mal!".

La combinación de "una pastilla rosada y una pastilla azul" (esquemas de Zidovudina, Entricitabina, Efavirenz o Tenoforvir) para Ricardo (como para muchos otros jóvenes awajún) fue la causa de mareos, cansancio, delgadez, brotes de heridas en la piel, alergias y pesadillas de persecución. La toma de fármacos era así una negociación diaria que afrontaba frente al peligro de sentirse cada vez más enfermo. Este camino no le fue fácil y como resultado interrumpió el tratamiento varias veces. Su objetivo era "dominar" las pastillas. Para el 2018, él decía con orgullo "ihasta tomo la pastilla sin comer!". Sin embargo, la amenaza onírica de ver tunchis persiguiéndolo y los mareos que le impedían hacer una vida cotidiana con su familia, alejaban a Ricardo del tratamiento antirretroviral. Los fármacos no le daban la vida que él quería, aunque por momentos repetía que volvería a tomarlos. El mensaje del personal de salud alentaba esa sensación de culpa frente al abandono del TARGA: "iEl que quiere vivir toma y el que quiere morir no toma!".

En nuestra conversación le pregunté si él había consumido toé u otras plantas para buscar otros diagnósticos. Él afirmó que no. Ricardo no se sentía cómodo con el toé. Cuando era más joven un miembro de su familia le hizo tomar toé para cambiar su "modo de ser". Él recuerda que la planta le presentó una visión aterradora y desconfiaba en volver a aproximarse a ella. 
Por ello, prefirió quedarse con sus dos diagnósticos: uno de "enfermedad de VIH" dado por el puesto de salud y otro de enfermedad curable dada por el herbalista. Sin embargo, le preocupaban los comentarios en su comunidad que asociaban el VIH/SIDA con el ser "maricón".

Ricardo, por momentos asociaba sus malestares al pecado. Las miradas, los discursos de anormalidad y las moralidades evangélicas comenzaron a hacer estragos en él, que por momentos se culpaba de estar enfermo. Ricardo tenía dudas de si debía seguir siendo él mismo, le daba temor alejarse de Apajui (Dios) y con eso de una vida "sana". Él decía: "De repente estoy pensando. Dios me va a dar castigo, porque me arrepiento itantas veces! de ser así maricón, y de vuelta vuelvo al pecado. Cuando estaba con Dios estaba bien, no tenia de que preocuparme. iEstaba sano!".

Frente a las dudas en torno a sus múltiples diagnósticos, Ricardo decía finalmente que su condición era un asunto exclusivo de él y de su familia. "La enfermedad de VIH es una verdad que solo saben uno, el obstetra del puesto y la familia". Ricardo le confió su diagnóstico también a un reconocido técnico sanitario awajún. Este especialista le dio esperanzas: "Debes tomar tus pastillas. Deja de tomar alcohol. Come bien. Cuídate con estas plantas. iAsí vas a estar bien!". Ricardo repetía con alivio este diagnóstico.

El caso de Ricardo era comentado en su comunidad. Algunas madres de jóvenes con "waweamu con síntoma de SIDA" comentaban los tratamientos de plantas que jóvenes como Ricardo consumían para controlar su enfermedad. La asociación de que él era un caso de játa y no de waweamu hacía clara la existencia de personas que podían vivir años con diagnósticos de VIH o SIDA del puesto de salud. La comunidad asociaba el uso de plantas como la catahua y el sacha jergón (Dracontium loretense krause) a esta vitalidad.

\section{Reflexiones finales}

Las dos trayectorias de padecimientos aquí narradas muestran las perspectivas awajún sobre VIH/SIDA asociadas a sus nociones de játa y waweamu. Estas perspectivas son centrales para pensar los "equívocos no controlados" (Kelly 2010) del conocimiento indígena y de los puestos de salud. Como hemos visto, estos conceptos awajún tienen significados complejos y responden a los cambios surgidos a consecuencia de la colonización y de la introducción de enfermedades no indígenas a sus territorios. Además, la diferencia entre ambas experiencias de malestar es porosa. Las sospechas de tener "waweamu con síntoma de SIDA" o "játa SIDA" se superponen constantemente y llevan a la búsqueda de nuevos caminos de cura. Para las 
familias awajún con las que trabajé, una separación discreta entre el daño y la enfermedad no era lo relevante. Es más una cuestión de modulación y no de exclusión. El VIH/SIDA no es una verdad que puede ser cernida con un solo tipo de causalidad y tratamiento. Si bien los Awajún reconocen que este padecimiento proviene de contextos apách y que los tratamientos antirretrovirales entregados por los establecimientos de salud del estado peruano son adecuados y necesarios; ellos también consideran que en sus comunidades los casos de VIH y SIDA han adquirido formas diferentes que requieren de cuidados cotidianos y de la búsqueda de diversos tratamientos que no corresponden al pensamiento apách. En consecuencia, la idea biomédica de una epidemia causada únicamente por replicación viral no es suficiente para explicar la experiencia del VIH/SIDA para una persona awajún. Los trabajos de Wiik (2001), con los indígenas Xokléng, y de Pina de Barros (2000) con los Bakairi, son propuestas interesantes para un abordaje antropológico del VIH/SIDA a partir de las nociones de persona, de cuerpo y de sus relaciones, alianzas e itinerarios terapéuticos que se despliegan en cada contexto.

Las dos historias aquí presentadas (de Elvis y Ricardo) destacan también la centralidad de las relaciones de convivencia, los cuidados y la percepción de la vulnerabilidad de los hijos para la constitución del parentesco, como argumentaron Overing \& Passes (2000), Gow (1989), McCallum (1998) y Belaunde (2001) en otros contextos etnográficos. Entre los Awajún afectados por VIH/SIDA, la memoria de los cuidados recibidos durante la infancia es reactualizada en los cuidados dados por la madre a su hijo enfermo, quien vuelve a ocupar una posición de entera vulnerabilidad. La madre asume la posición central de dar vida y crea en su cocina el espacio de cuidado principal. Su protagonismo como cuidadora es posibilitado por la confluencia de acciones de otros miembros de su red de parentesco y por la dinámica de los que conviven en su casa. Es decir, la enfermedad reactiva los esfuerzos para seguir produciendo cuerpos conocedores y saludables. Tomando prestado las palabras de McCallum (1998), sugiero que los cuidados y los procesos de resguardo otorgados por la madre y las familias tienen el objetivo de "hacer saber" y "hacer conocer" nuevamente al cuerpo debilitado de sus hijos.

La madre hace cuerpos y hace memorias, ella mantiene dinámica las redes de relación en torno al hijo enfermo. Este protagonismo de la madre como generadora de fuerza y memoria en los tiempos de padecimiento ha sido observada en otros contextos etnográficos donde el dolor y el peligro de muerte son inminentes, como en el estudio de Belaunde (2003) sobre las narraciones del parto entre los Yine. Las narraciones de las mujeres Yine 
sobre sus experiencias de parto resaltan el recuerdo de la madre y de sus enseñanzas que sustentaron la determinación de parir "haciendo fuerza", dando continuidad al parentesco. De igual manera, las madres awajún encaran el tiempo de la enfermedad de sus hijos llenándolo de su fuerza; lo habitan buscando generar vida y construyen en él narraciones sobre el cuidado de sus hijos. Ellas actúan, tejen relaciones, crean memorias y transmiten conocimientos surgidos de sus experiencias diarias con el VIH/SIDA. Los tratamientos y cuidados son narrados y compartidos en familia; en la repetición de estas memorias se instruye a los oyentes a interpretar sus propias experiencias de enfermedad en la vida cotidiana (Langdon 2001: 257).

Según el complejo conocimiento del cuerpo awajún, todos los aspectos de las personas, sus órganos internos, sus extremidades, sensaciones, actitudes, y pensamientos pueden ser afectadas por agentes externos. Por ello, las familias awajún están constantemente alertas ante la posibilidad de volverse "no vidas" o cuerpos que "viven enfermos". Estas expresiones son usadas por las madres cuando hacen referencia a la enfermedad de sus hijos y a la manera como sus vidas se ven limitadas porque no pueden realizar las actividades cotidianas. El estar enfermo es el comienzo de un estado de "no vivir". Es un pliegue de la vida sobre sí misma y un tiempo en el que toda la existencia de la familia es absorbida por los intentos de generar nueva fuerza y vida a un miembro enfermo. El pensamiento awajún no tiene como fin posicionarse con una verdad única sobre cómo atender el cuerpo enfermo. El objetivo de la madre y de la familia en torno de ella es la cura, y esta se presenta un campo de posibilidades muy amplio, que involucra a especialistas biomédicos e indígenas y agentes de curación humanos y no humanos, especialmente, las plantas. Las redes familiares generan estrategias heterogéneas para cada caso en el que intentan responder al estado particular del enfermo.

Las señales de peligro son claras para los Awajún. Como Ricardo y Elvis lo evidenciaron, la imposibilidad de comer es uno de los primeros síntomas de alerta. Este se asocia directamente al enflaquecimiento, a la perdida de movilidad y al quedarse postrado en una cama. La cocina y los ambientes anexos son los espacios centrales de cuidado en la casa awajún. En ellas se disponen las camas de madera que aseguran que la persona enferma esté permanentemente acompañada. Con el hijo enfermo en la cocina, las madres hacen un seguimiento detallado y diario de cada signo de alerta: cuándo y qué comió; qué alimentos lo empeoraron o mejoraron; qué plantas tomó; qué medicamentos probó, cuándo perdió la capacidad de hablar; cuántos días no pudo levantarse de la cama; y qué excreciones salieron de su cuerpo. 
El intenso cuidado materno dentro la cocina transforma a la casa en una entidad viva donde las relaciones familiares se entretejen con substancias, subjetividades, narraciones, acciones y pugnas, por medio de las cuales los parientes intentan devolver fuerza al cuerpo de sus hijos enfermos. Es un terreno de disputas en la búsqueda de salud que dialogan con las propuestas teóricas y etnografías realizadas fuera de la Amazonía, como el estudio de Carsten (2004) en Malasia donde la casa familiar se percibe como la materialización de los nexos de relaciones de las personas que las habitan. También hacen eco a la "economía de co-residencia" planteada por Madi (2018a) en su análisis de la cocina y la constitución mutua de la casa, el parentesco y el género entre los Guna de Panamá. Además, estos entretejidos de redes de cuidado permiten aproximarse al sufrimiento como una categoría antropológica de particular relevancia para comprender la maternidad en situaciones de precariedad, como argumenta Das (2011) en su estudio con mujeres en la India. La centralidad de la cocina awajún, como lugares de alimentación, alegría y, al mismo tiempo, de padecimiento y cuidado de los hijos enfermos, muestra que la familia es una fuente de dolor, de dificultad, de tensión, de afecto, de fugas y de imaginaciones que forman parte de una política de afectos que permite rehabitar el cotidiano y generar vida frente a episodios de sufrimiento.

Cada acto de cuidado dado por las madres awajún a sus hijos es la concretización del entramado de estas relaciones que dan forma constantemente al cuerpo, a la casa y al parentesco. El cuerpo enfermo y dañado del hijo vuelve a un estado vulnerable, que necesita el cuidado de la madre y la red del parentesco en torno de él. Ahora entiendo mejor porque cuando la señora Tania me narraba los cuidados que le daba a su hijo, ella repetía siempre: "iYo le ayudaba a hacer todo! A sus heces, a que coma. A todo a mi hijito" y Elvis respondía: "Antes no dejaría que me vieras así, me daría vergüenza. Ahora me limpias tú mamá".

Si no fuese por las memorias que las madres de familia me brindaron generosamente no hubiera podido acceder al complejo pensamiento awajún sobre el VIH/SIDA. Termino entonces este artículo con una reflexión de orden teórico y metodológico con el propósito de establecer un puente con los estudios epidemiológicos y las políticas públicas sobre VIH/SIDA en los pueblos indígenas amazónicos. Para abordar esta alarmante epidemia en el contexto awajún y pensar en modos para enfrentarla, es necesario acercarse a las madres, escuchar sus memorias, sus demandas y conocer sus modos de volver a generar vida. El protagonismo de las madres y la subjetividad de los hijos seropositivos nos llaman para explorar el sufrimiento y el vitalismo que se entretejen en cada una de sus experiencias de cuidado. 
Recibido el 22 de mayo de 2019

Aprobado el: 11 de septiembre de 2019

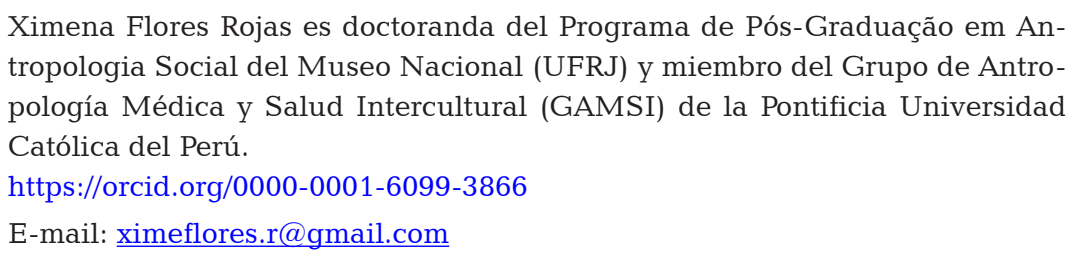

\section{Notas}

* Este texto es parte de mi investigación de maestría defendida en el PPGAS/ MN/UFRJ. Agradezco a Luisa Elvira Belaunde, orientadora principal de mi investigación, por su lectura detallada y aportes claves para el desarrollo de este artículo. Asimismo, agradezco a mis examinadores, Aparecida Vilaça y Diego Madi, por sus cuidadosos comentarios.

1 Los Awajún pertenecen a la familia lingüística Jíbaro y son la segunda población indígenas amazónica más numerosos del Perú. El distrito de El Cenepa se encuentra en la provincia de Condorcanqui, en la región Amazonas. Este territorio oscila entre los 210 y 230 MSNM. Tiene una población de 9891 personas, $86 \%$ de los cuales se autoidentifica como awajún. En este artículo utilizo la palabra en mayúsculas "Awajún" cuando me refiero al sustantivo (nombre).

2 Según personal de la Micro Red de Salud Huampami (2018) la primera muerte de "SIDA" en el distrito de El Cenepa fue en el 2005. Sin embargo, otros estudios reportan esta primera muerte en el 2006 (Lazo 2014), e incluso, 2007 (Pintado 2016).

3 Término usado para designar a las personas consideradas no indígenas. A los extranjeros no peruanos se les puede llamar también de "gringos".

4 La palabra awajún "setash" es un término coloquial utilizado por adolescentes y jóvenes awajún para referirse a la "enfermedad del SIDA". 
5 El sistema de salud pública en el distrito de El Cenepa se distribuye en 19 Puestos de Salud y 01 Centro de Salud. Los Puestos de Salud funcionan con un técnico sanitario awajún y, de acuerdo con la demanda poblacional, cuentan con especialistas de salud apách (obstetras, enfermeros y técnicos de laboratorio). Desde el inicio de la epidemia estos establecimientos de salud han adoptado medidas de tamizaje y acompañamiento a los casos seropositivos en su jurisdicción.

6 Los iwanch, antiguamente eran asociados a espíritus del mundo de los muertos. Las misiones asociaron el concepto de Iwanch directamente con el diablo (Riol 2015).

7 Brown (1984) identifica esta visión como niimangbau o visión de vida futura. Esta visión muestra la descendencia, matrimonios, viajes, bienes materiales y oficios futuros. Luego de ella, la persona ahora con visión vivirá ese camino: "esa persona cuando es vieja vive igual" (Rubén, Cenepa 2018).

8 La sexualidad awajún requiere un abordaje exhaustivo. Los estudios de Madi (2018b) y Cariaga (2015) son referencias para entender otros casos etnográficos. 


\section{Bibliografía}

ALBERT, Bruce \& GOODWIN, Gale. 1997. Saúde Yanomami. Belém: Museu Paraense Emílio Goeldi.

AGOSTINI, Rafael; MAKSUD, Ivia \& FRANCO, Tulio. 2018. "Eu tenho que te contar um negócio": gestão da soropositividade no contexto dos relacionamentos afetivo-sexuais dos jovens vivendo com HIV. Sexualidad, Salud y Sociedad. 3: 201-223.

BELAUNDE, Luisa. 2001. Viviendo Bien. Género y fertilidad entre los airo pai de la Amazonía Peruana. Lima: CAAAP.

.2003 "Yo solita haciendo fuerza: Historias de parto entre los Yine (Piro)". Amazonía Peruana. 28-29: 125-147.

BROWN, Michael. 1984. Una paz incierta. Historia y cultura de las comunidades aguarunas frente al impacto de la carretera marginal. Lima: CAAAP.

BUCHILLET Dominique. 2004. "Sorcery Beliefs. Transmission of Shamanic Knowledge, and Therapeutic Practice among the Desana of the Upper Río Negro, Region, Brazil". In Darkness and Secrecy. London: Duke University Press.

CARIAGA, Diogenes. 2015. "Gênero e sexualidades indígenas: alguns aspectos das transformações nas relações a partir dos Kaiowa no Mato Grosso do Sul". Cadernos de campo, 24: 441-464.

CARSTEN, Janet. 2004. After kinship. New York: Cambridge University.

DAS, Veena. 2011 "O ato de testemunhar: Violência, gênero e subjetividade". Cadernos Pagu. 37: 9-41.

DIEHL, Eliana \& GRASSI, Francielly. 2010. "Uso de medicamentos em uma aldeia guarani do litoral de Santa Catarina, Brasil". Cad. Saúde Pública, Rio de Janeiro, 26(8):1549-1560
FARMER, Paul \& CASTRO, Arachu. 2005. "El estigma del sida y su evolución social: una visión desde Haití". Revista de Antropología Social. 14: 125-144.

GARNELO, Luiza \& BUCHILLET, Dominique. 2006. "Taxonomias das doenças entre os índios Baniwa (Arawak) e Desana (Tukano oriental) do alto rio negro (Brasil)" Horizontes Antropológicos. Porto Alegre, 12 (26): 231-260.

GOW, Peter. 1989. "The perverse child: Desire in the native Amazonian subsistence economy". Man. 24: 567-582

HUAMÁN, Byelca; GUSHIKEN, Alfonso; BENITES, Carlos; QUIROZ, Fabiola \& GARCÍA, Lisset. 2017. "Prevención de la transmisión materno-infantil del VIH en gestantes y madres awajún y wampis de la región amazonas en Perú". Revista Peruana de Medicina Experimental y Salud Pública. 34 (4): 627-632

KELLY, José. 2003. Relations within the Health System among the Yanomami in the Upper Orinoco, Venezuela. Ph.D. Dissertation, University of Cambridge.

. 2010. "Os Encontros de Saberes? equívocos entre índios e Estado em torno das políticas de saúde indígena na Venezuela". Ilha. 11(2): 265-302.

KLEINSMAN, Arthur. 1978. "Concepts and a model for the comparison of medical systems as cultural systems". Social Science and medicine. 12: 85-93.

KOPENAWA, David \& ALBERT, Bruce. 2015. A queda do céu: palavras de um xamã yanomami. São Paulo: Companhia das letras.

LAZO, Rodrigo. 2014. Informe etnográfico para propuestas de modificatoria a la NTS de VIH y SIDA para población Awajún de Condorcanqui - Amazonas. Documento de trabajo. 
LANGDON, E. Jean. 2014. La negociación de lo oculto: chamanismo, medicina y familia entre los siona del bajo Putumayo. Popayan: Universidad del Cauca.

. 2001. "A doença como experiência: o papel da narrativa na construção sociocultural da doença". Etnográfica. 2: 241-260.

MADI, Diego. 2018a. Entre a infância e o sonho: pedagogia Guna da autonomia (Panamá). Documento de trabalho.

. 2018b. O parentesco Transviado. Exemplo Guna (Panamá). Documento de trabalho.

MARGULIES, Susana; BARBER, Nélida \& RECODER, María. 2006. "VIH-SIDA y adherencia al tratamiento: enforque y perspectivas". Antipoda. 3: 281-300.

MCCALLUM, Cecilia. 1998. "O corpo que sabe da epistemologia Kaxinawa para uma antropologia médica das terras baixas sul-americanas". ALVES, PC., and RABELO, MC. orgs. Antropologia da saúde: traçando identidade e explorando fronteiras. Rio de Janeiro: FIOCRUZ. p. 215245.

MENÉNDEZ, Eduardo. 2015. ¿̇Las enfermedades son sólo padecimientos? En: Jornada sobre antropologia i pluralisme assistencial. Universitat Rovira i Virgili.

MICRORED DE SALUD HUAMPAMI. 2018. Distrito El Cenepa: Número de casos de VIH/SIDA [Cuadro estadístico]. Informe del área de estadística. MINISTERIO DE SALUD (MINSA) \& FONDO DE POBLACIÓN DE LAS NACIONES UNIDAS (UNFPA). 2009. Una aproximación cualitativa a la prevención del VIH-Sida en dos comunidades nativas de Ucayali. Lima: IES.
ORELLANA, Roberto; ALVA, Isaac; CÁRCAMO Cesar \& GARCIA, Patricia. 2013. "Structural factors that increase HIV/STI vulnerability among indigenous people in the Peruvian amazon". Qual Health. .23(9):1240-1250.

ORELLANA, Roberto \& ALVA, Isaac. 2012. "Social and contextual factors that influence HIV risk behaviors among indigenous MSM in the Peruvian Amazon". Retrovirology. 9:112.

OVERING, Joanna. \& PASSES, Alana (eds). 2000. The Anthropology of Love and Anger: the aesthetics of conviviality in Native Amazonia. London: Routledge.

PÉREZ-GIL，Laura. 2001. "O sistema médico Yawanáwa e seus especialistas: cura, poder e iniciação xamânicas". Caderno de Saúde Pública. 17 (2): 333-344.

PINA DE BARROS, Edir. 2000. "El sida: representaciones indígenas y políticas sociales". Gazeta de Antropología. 16. Artículo 03.

PINTADO, Isaías. 2016. "La implementación de políticas públicas en salud para los pueblos indígenas de Santa María de Nieva en Amazonas: la tensión entre la atención al VIH-SIDA y el enfoque intercultural" Tesis de Maestría. PUCP.

RED DE SALUD CONDORCANQUI. 2018. Reporte de casos de VIH entre 2010 -2018. [Base de datos]. Informe del área de estadística.

RIOL, Raúl. 2015. La construcción del Cenepa como lugar indígena: Una historia Awajún y Wampis de relación y defensa del territorio. Tesis de doctorado. Universidad Autónoma de Madrid. 
SECRETARÍA INTERNACIONAL DE PUEBLOS INDÍGENAS FRENTE AL VIH, LA SEXUALIDAD Y LOS DERECHOS HUMANOS - SIPIA \& ONUSIDA. 2016. "Estado del Arte sobre VIH y Pueblos Indígenas en América Latina". Informe.

SEEGER, Anthony; DA MATTA, Roberto \& VIVEIROS DE CASTRO, Eduardo. 1979. "A construção da pessoa nas sociedades indígenas brasileiras". Boletim do Museu Nacional. Antropologia. $\mathrm{N}^{\circ}$ 32: 1-19.

VILAÇA, Aparecida. 2006. Quem somos nós: os Wari' encontram os brancos. Rio de Janeiro: UFRJ. . 2008. "Conversão, predação e perspectiva". Mana. 14: 173-204.

VIVEIROS DE CASTRO, Eduardo. 2004.
"Perspectival anthropology and the method of controlled equivocation". Tipití: Journal of the Society for the Anthropology of Lowland South America. 2 (1):3-22.

WIIK, Flavio. 2001. "Contato, epidemias e corpo como agentes de transformação: um estudo sobre a AIDS entre os Índios Xokléng de Santa Catarina, Brasil". Caderno Saúde Pública. 17(2): 397-406, mar-abr.

ZAVALETA, Carol; MUJICA, Jaris; YPANAQUÉ, Pedro \& CUEVA, Neptalí. 2007. "Infecciones de transmisión sexual y VIH/SIDA en comunidades nativas de la Amazonía peruana: consideraciones culturales". Salud Publica. 24(3):315-316. 


\section{ENTRE JÁTA Y WAWEAMU: VIH/SIDA EN LAS COMUNIDADES AWAJÚN DE LA \\ AMAZONÍA PERUANA}

\section{Resumen}

Este artículo tiene por objetivo presentar las nociones y experiencias awajún de vivir con VIH/SIDA. Los Awajún del distrito de El Cenepa, expresa su comprensión del VIH/SIDA como condición apách (no indígena) por medio de las expresiones "játa SIDA" y "waweamu con síntoma de SIDA" que designan sus nuevas nociones de enfermedad y daño (brujería). Estas concepciones awajún conjugan dimensiones corporales, sociales y espirituales que se entrelazan en la multiplicidad de lo que es "estar enfermo". Con base en el análisis de dos historias de vida (Elvis y Ricardo), propongo mostrar los caminos de búsqueda de salud y la compleja relación desplegada por las familias awajún, especialmente por las madres de las personas afectadas por esta epidemia.

Palabras clave: VIH; SIDA; awajún; enfermedad; brujería y cuidado.

\author{
ENTRE JÁTA E WAWEAMU: \\ HIVIAIDS EM COMUNIDADES \\ AWAJÚN DA \\ AMAZÔNIA PERUANA
}

\section{Resumo}

Este artigo tem como objetivo apresentar as noções e as experiências awajún no viver com HIV/AIDS. A população de Awajún do distrito de El Cenepa expressa sua compreensão do HIV/ AIDS como uma condição apách (não indígena) por meio das expressões "játa SIDA" e "waweamu com sintoma de SIDA", expressões que designam suas novas noções de doença e feitiçaria. Estas concepções awajún conjugam dimensões corporais, sociais e espirituais que se entrelaçam na multiplicidade do que é "estar adoecendo". Com base na análise de duas histórias de vida (Elvis e Ricardo), proponho mostrar os caminhos da busca pela saúde e da complexa relacionalidade apresentada pelas famílias awajún, especialmente pelas mães, das pessoas afetadas por essa epidemia

Palavras chave: HIV; AIDS; awajún; doença; feitiçaria e cuidado. 
BETWEEN JÁTA AND WAWEAMU:

HIV/AIDS IN AWAJÚN

COMMUNITIES OF THE

PERUVIAN AMAZON

\section{Abstract}

This article presents the notions and experiences of awajún people living with HIV/AIDS. The awajún population of "El Cenepa" district express their understanding of HIV/AIDS as an apách (non-indigenous) condition; using the expressions "játa SIDA" and "waweamu con síntoma de SIDA", portraying their novel notions of sickness and sorcery. These awajún conceptions conjugate different corporal, social and spiritual levels that intertwine with the multiplicity of what it means to "be sick". Based on the analysis of two life stories (of Elvis and Ricardo), I show the paths taken in search of health and the complex relationality displayed by families, especially mothers, of the people affected by this epidemic.

Key words: HIV; AIDS; awajún; sickness; sorcery and care. 